\title{
THE EFFECTIVENESS OF FLIPPING CLASSROOM MODEL ON EFL SECONDARY SCHOOL SPEAKING SKILLS
}

\author{
Yahya Ashour AlKhoudary \\ Al Buraimi University College, Al Buraimi, the Sultanate of Oman \\ E-mail: alkhoudary@buc.edu.om \\ Jehad Ashour AlKhoudary \\ Al Buraimi University College, Al Buraimi, the Sultanate of Oman \\ E-mail: alkhoudary@buc.edu.om
}

\begin{abstract}
APA Citation: AlKhoudary, Y. A., \& AlKhoudary, J. A. (2019). The effectiveness of flipping classroom model on EFL secondary school speaking skills. Indonesian EFL Journal, 5(2), 1-10. doi: 10.25134/ieflj.v5i2.1811.
\end{abstract}

Received: 01-03-2019

Accepted: 11-05-2019

Published: 01-07-2019

\begin{abstract}
This study examines the impact of flipped learning on ESL students' speaking skills. Basically, secondary school students lack out-of-class instruction to review and study teaching materials independently since there is no opportunity to practice speaking skills outside the class. Therefore, the availability of the technological device in everyone's hand may help to enhance speaking if they are monitored regularly. The qualitative and quantitative approach is employed. The participants consisting of (40) Omani secondary school students, were divided into two groups (20) in the Experimental Group (E. G) and (20) in the Controlled Group (C.G). Pre-and post-tests were managed to both groups before using flipped classroom (FC) as a scaffolding of teaching speaking to non-native learners. Besides, a questionnaire was administered to. The results revealed that E.G excelled in the C.G. Also, it showed a positive attitude towards flipping as a learning strategy.

Keywords: flipped classroom; skills; technological devices; English as a foreign language; traditional class.
\end{abstract}

\section{INTRODUCTION}

Speaking is the most important among the four language skills since ESL learners need using the English Language in a virtual context. Since graduate students are prepared to join higher education, then to be involved in serving the country, they need to be able to communicate with tourists, visitors and participate in classroom activities. This study aims to look for all possibilities to employ FC in an ESL class to explore the effect of this strategy on students' speaking quality. Further, the increase focuses on competencybased teaching and learning to boost learner's independent learning. However, non-native learners always find difficulty to participate in classroom activities since English is not their primary language. Therefore, teachers work hard to come out with eligible students who can communicate with native speakers in a virtual situation successfully. Since technological devices have become a habit among students worldwide, they spend the most time on chatting and accessing websites. So, no doubt integrating technology in teaching has become an important factor to achieve effective learning.

This study emerges from the researcher's experience in ESL classes that the teacher is the information provider and students are receivers in boring classes since they cannot discuss debate and participate effectively in the lesson. They lack chances to acquire understandable input and send incomprehensible output. Therefore, it is necessary to find out an innovated method to give students enough opportunities to be exposed to English and to improve speaking. So, technology may contribute to enhance learning input since diverse devices are available in everyone's hand. FC is an instructional model that furnishes blended online learning to explore the effect of the flipped model on non-native learners at secondary schools. Additionally, educators have to exploit technological devices to 
develop students' speaking competence since it is a means of instruction in universities since traditional education has become ineffective because of the changing needs of students in the era of technology.

This study attempts to explore the probability of using FC model in speaking classroom in Oman. This paper attempts to examine to what extent e-learning contributes to improving learners' speaking output. Thus, the objectives of the study are (1) To investigate the applicability of using FC model in ESL class, (2) To check the impact of employing FC on speaking skills, (3) To create a competitive atmosphere of using technology in the classroom, (4) To support further research in the field of teaching ESL in Oman.

The hypotheses in this study are (1) Students who are engaged in FC improve their speaking product, (2) FC increases students' confidence to work independently, and (3) Students who are in FC show a positive attitude towards technology. Fleming (2001) claims that visual learners prefer seeing (think in pictures; visual aids such as overhead slides, diagrams, handouts, etc.). Auditory best learn through listening (lectures, discussions, tapes, etc.). Therefore, technology has become a tool to serve as a platform for the instruction of the content. Besides, Bloom's Taxonomy of knowledge and social constructivism will be used in the FC model (Brame, 2013: 12). Rababah (2003) states that FC shows that students get a first exposure to prescribed material off class. He maintains that Arab learners are struggling in speaking skills due to strategies teachers employ in classrooms. Berrett (2012) argues that flipping is arranged to give learners enough opportunity to complete lower cognitive thinking outside of the class, whereas the higher one of cognitive is done inside the class-walls. Flipped classroom model is based on blended learning studentcentered approach (Abeysekera \& Dawson; 2015, Clark, 2015). It also covers some pedagogies focusing on students' engagement in the learning process (Lemmer, 2013; Prince, 2004).
This study attempts to answer several questions, which are (1) to what extent does the FC model affect learners' speaking output? (2) How can FC make the best use of teaching time in class? (3) Does FC change students' attitudes toward integrating technology in education? (4) Is the FC model applicable in ESL speaking classroom? Traditional classrooms have generated a great number of students who are unable to use English neither in nor outside the classroom. Rivero (2013) states that teachers who experimented with this strategy indicate $\mathrm{FC}$ is a positive learning experience. Avdic \& Akerblom (2015) argue that FC increases motivation, self-perceived knowledge, and performance. Little research has been focusing on FC. So, this study is an attempt to try the model in teaching ESL secondary school classrooms.

Flipping model is a creative way for educators to maximize class time for students' involvement in practice speaking skills. It is known as the reversed instruction and inverted classroom (Bergmann \& Sams, 2012). Kikgoz (2011) affirms that FC grants students the flexibility to work willingly at their own pace. The flipped learning helps teachers to reflect on the effectiveness of his teaching strategy and try to avoid a boring daily teaching routine. Flipped classes offer chances to diverse learning ways (Oxford, 2003, p. 1). Brame (2013) suggestS that FC includes opportunities for leaner's to get input prior to the class, encouragement to prepare before the class, assess students' progression, and focus on cognitive activities. Johnson et al (2014) state that flipping learning as an element of blended learning can be used in teaching and learning since it complies with online and classroom teaching. Sams \& Bergmann (2013) ascertain that FC is considered a new pedagogic model that trains learners to have responsibility for their learning under the guidance of the teacher. They add that teachers can create healthy learning environments in which students have chances to enhance their language skills. Flipped classroom model has two stages: (1) learning individually with the 
help of technology of the class, (2) learning occurs inside the class (Bishop \& Verleger, 2013). In this reverse learning, homeassignment in traditional education turns into activities in-class and class activities are conducted at home online. On the one hand, learners who have learned speaking via conventional education resist the new strategy (Herreid \& Schiller, 2013). Kirkwood \& Price (2005) state that students and teachers feel that technology can be an effective tool to enhance learners' language skills. Furthermore, Engin (2014) ascertain that a flipped classroom model gives students a room to develop their language skills.

Additionally, Nguyen (2013) proposes that a flipping classroom motivate learner autonomy towards learning achievement. The proposed flipped classroom includes (1) opportunities for learners to be exposed to input former the class, (2) encouragement for learners to prepare materials before the class, (3) a way to check students' understanding, (4) instigate cognitive abilities (Brame, 2013). Flipping give students enough opportunities to improve students' speaking skills since they easily access to their assignment. Nguyen, \& Quyen (2018) state that flipped instruction developed students' speaking since this system effectively and flexibility enables students to watch videos wherever and whenever to enhance their language proficiency. Wiginton (2013) indicates that flipped instruction is an education model that employs technology to change the situation of the classroom.

Additionally, Lin (2002) ascertains that students with good listening comprehension abilities help them to immerse in-classactivities efficiently. Students who use the flipped classroom can get curricular activities outside the class easily at their own pace (AlHarbi \& Alshumaimeri, 2016; Demski, 2015). Interestingly, the online community creates a healthy learning atmosphere that enhances learners' oral speaking quality ( $\mathrm{Wu}$, Chen, \& Yang, 2017) Osgerby (2012) ascertains that students hate group work and lecturing but they prefer blended learning that includes technology in the regular class situation.

\section{METHOD}

To answer the current research questions and to test the proposed hypotheses, an experimental treatment was applied to explore the effectiveness of integrating $\mathrm{FC}$ in teaching writing skills. A mixed approach was used to come out with accurate data that confirms the validity of using such a probe among BUC students in Oman.

The sample of this study consisted of (40) students who were selected randomly and divided into two groups E.G (20) and C.G (20) Omani female students in the first year who were taking an introductory writing course in the English Language at a Secondary School. Ten ESL teachers were included in this study. The participants were asked to do both online and offline speaking activities using the recorded materials downloaded by the teacher on Google Classroom. They were trained to access using a code and watch recorded guidelines on video-clip at home.

The pre-speaking test was administered to both E.G and C.G. to check the effect of employing FC in the ESL classroom. A questionnaire was also distributed to E.G. after using the flipping model to determine its effect on speaking quality and to measure students' attitudes towards FC. Also, interviews were conducted with E.G and ESL teachers after application. The participants in the study were given orientation and training on using Google Classroom to prepare for the virtual speaking, watching videos, listen to recorded materials, check and use active vocabulary, use the downloaded Pictionary. The following diagram displays what activities students were expected to do at both schools and home. A pilot student was conducted on a small group of students to check the reliability of the questionnaire questions since they addressed adults who are of the same age and learned English according to the Ministry of Education curriculum in Oman. 
The effectiveness of flipping classroom model on EFL secondary school speaking skills

\section{Reliability}

Cronbach's alpha coefficient for the questionnaire is (0.912) which is a high coefficient, which indicates that the questionnaire is highly reliable. To ensure that Ex. and Cont. G. samples are equivalent in their previous speaking test since the researcher administers the speaking test before incorporating a flipped classroom model. The result of the subjects was recorded and statistically analyzed by using Independent Sample T-test. Table 1 demonstrates the mean and Std.D, t. value, pvalue and significant level of each group in English language speaking tests.

Table 1. Mean, St.D, $t$ value, p-value significant level of $C$ and $E$. $G$ in English speaking

\begin{tabular}{|c|c|c|c|c|c|c|}
\hline \multicolumn{7}{|c|}{ pretest } \\
\hline Category & $\mathbf{G}$ & $\mathbf{M}$ & S.D. & $t-v$ & p- v & Sig. \\
\hline Fluency \& & $\mathrm{E}$ & 3.20 & 1.94 & \multirow{2}{*}{0.403} & \multirow{2}{*}{0.698} & \multirow{2}{*}{ No sig } \\
\hline Coherence & $\mathrm{C}$ & 3.45 & 1.99 & & & \\
\hline Content / & $\mathrm{E}$ & 4.40 & 2.35 & \multirow{2}{*}{0.405} & \multirow{2}{*}{0.688} & \multirow{2}{*}{ No sig } \\
\hline Vocabulary & $\mathrm{C}$ & 4.10 & 2.34 & & & \\
\hline Pronunciation/ & $\mathrm{E}$ & 4.65 & 2.18 & \multirow{2}{*}{0.671} & \multirow{2}{*}{0.506} & \multirow{2}{*}{ No sig } \\
\hline Intonation / Stress & $\mathrm{C}$ & 4.15 & 2.52 & & & \\
\hline Posture \& eye & $\mathrm{E}$ & 4.10 & 2.22 & \multirow{2}{*}{0.336} & \multirow{2}{*}{0.739} & \multirow{2}{*}{ No sig } \\
\hline contact/ Enthusiasm & $\mathrm{C}$ & 3.85 & 2.48 & & & \\
\hline Grammatical Range & $\mathrm{E}$ & 4.50 & 2.59 & \multirow{2}{*}{0.677} & \multirow{2}{*}{0.502} & \multirow{2}{*}{ No sig } \\
\hline Accuracy & $\mathrm{C}$ & 4.00 & 2.05 & & & \\
\hline Total & $\mathrm{E}$ & 20.85 & 5.11 & 0.785 & 0.437 & No sig \\
\hline
\end{tabular}

Table 1 demonstrates that the computed (T) value is lower than the critical (T) value. This result means that there are no statistically significant differences at $(\alpha \leq$ 0.05 ) between the mean scores of E. and C.G in the level of speaking-achievement pre-test. This result means that the experimental and control groups are equivalent and homogeneous in their speaking skills level.

\section{RESULTS AND DISCUSSION}

The first hypothesis "There are statistically significant differences at $(\alpha \leq 0.05)$ in the level of speaking skills between the mean scores of Ex. G in the pre-test and post-test." To examine the first hypothesis, the researcher used the Paired Sample T-test to calculate the differences between the mean scores of E.G in speaking pre-test and posttest. The results were displayed in table 2.

Table 2. Mean, St.D, $t$ value, p-value, the significant level between E.G mean scores of pretest and post-test

\begin{tabular}{lcccccc}
\hline \multicolumn{1}{c}{ Category } & G & M & S.D. & t-v & p- v & Sig. \\
\hline Fluency \& & E & 3.20 & 1.94 & 6.240 & 0.00 & 0.01 \\
Coherence & C & 4.90 & 1.68 & & & \\
Content / & E & 4.40 & 2.35 & 7.310 & 0.00 & 0.01 \\
Vocabulary & C & 5.85 & 2.01 & & & \\
Pronunciation/ & E & 4.65 & 2.18 & 5.715 & 0.00 & 0.01 \\
Intonation /Stress & C & 6.05 & 1.85 & & & \\
Posture \& eye & E & 4.10 & 2.22 & 3.928 & 0.00 & 0.01 \\
contact/ Enthusiasm & C & 5.20 & 2.02 & & & \\
Grammatical Range & E & 4.50 & 2.59 & 7.855 & 0.00 & 0.01 \\
Accuracy & C & 5.95 & 2.42 & & & \\
Total & E & 20.85 & 5.11 & 9.170 & 0.00 & 0.01 \\
\hline
\end{tabular}

** $\mathrm{t}$, critical value at df 19 and sig level $0.01=2.861$

$* \mathrm{t}$, critical value at df $19 \mathrm{sig}$ level $0.05=2.086$ 
Table 2 shows that the computed (T) value is higher than the critical (T) value at the degree of freedom 49 and a significant level (0.01). This result means that there are statistically significant differences at $(\alpha \leq$ $0.05)$ in the level of speaking skills between the mean scores of E.G in the pre-test and post-test in favor of the post-test. (This means that using flipped classroom improved speaking skills of the student using FC). The second hypothesis "There are no statistically significant differences at $(\alpha \leq 0.05)$ in the level of speaking between the mean scores of E.G and C.G in post-test". To examine the $2^{\text {nd }}$ hypothesis, the researcher used the Independent Sample T-test to determine the differences between the mean scores of E. G and C.G in speaking achievement post-test as shown in table 3 .

Table 3. Mean, St.D, $t$ value, p-value significant level between C. and E. G mean scores in speaking post-test

\begin{tabular}{lcccccc}
\hline \multicolumn{1}{c}{ Category } & G & M & S.D. & t-v & p- v & Sig. \\
\hline Fluency \& & E & 4.90 & 1.68 & 2.777 & 0.01 & 0.01 \\
Coherence & C & 3.35 & 1.84 & & & \\
Content / & E & 5.85 & 2.01 & 2.983 & 0.00 & 0.01 \\
Vocabulary & C & 3.90 & 2.13 & & & \\
Pronunciation/ & E & 6.05 & 1.85 & 2.780 & 0.01 & 0.01 \\
Intonation /Stress & C & 4.15 & 2.43 & & & \\
Posture \& eye & E & 5.20 & 2.02 & 2.378 & 0.02 & 0.01 \\
contact/ Enthusiasm & C & 3.50 & 2.48 & & & \\
Grammatical Range & E & 5.95 & 2.42 & 2.751 & 0.01 & 0.01 \\
Accuracy & C & 4.00 & 2.05 & & & \\
Total & E & 27.95 & 5.19 & 6.084 & 0.00 & 0.01 \\
\hline
\end{tabular}

** $\mathrm{t}$, critical value at df 38 and sig level $0.01=2.704$

$* \mathrm{t}$, critical value at df $38 \mathrm{sig}$ level $0.05=2.021$

Table 3 shows that the computed (T) value is higher than the critical $(\mathrm{T})$ value at a degree of freedom 98 and a significant level (0.01) for speaking skills post-test. This result means that there are statistically significant differences at $(\alpha \leq 0.05)$ in the level of speaking between the mean scores of E. and C.G in the post-test in favor of E.G.
There are differences between the students using flipped classroom models and those learning to speak in conventional classrooms in favor of students using a flipped classroom. $\eta 2$ were computed to determine the effectiveness of using FC in developing speaking as shown in table 4 .

Table 4. Eta square coefficients of the effect size of using FC model on speaking skills

\begin{tabular}{lcccc}
\hline \multicolumn{1}{c}{ Category } & T value & $(\boldsymbol{d} \boldsymbol{f})$ & $\boldsymbol{\eta}^{2}$ & Effect \\
\hline Fluency\& Coherence & 6.240 & 19 & 0.672 & high \\
Content / Vocabulary & 7.310 & 19 & 0.738 & high \\
$\begin{array}{l}\text { Pronunciation/ } \\
\text { Intonation / Stress }\end{array}$ & 5.718 & 19 & 0.632 & high \\
$\begin{array}{l}\text { Posture \& eye contact/ } \\
\text { Enthusiasm }\end{array}$ & 3.928 & 19 & 0.448 & high \\
$\begin{array}{l}\text { Grammatical Range } \\
\text { Accuracy }\end{array}$ & 7.855 & 19 & 0.765 & high \\
Total & 9.170 & 19 & 0.816 & high \\
\hline
\end{tabular}

Table 4 shows that $\eta 2=0.816$ which means that using a flipped classroom in learning the English language has a high effect on developing students' speaking skills. The result of the $1^{\text {st }}$. and $2^{\text {nd }}$ hypotheses indicate that the speaking level of the students who use FC is higher than those who learned that skill via traditional 
classroom only. How does technology impact students' attitudes toward flipping learning? Means, standard deviation and proportional mean were calculated to determine the E.G attitude towards flipping learning as shown in table 5.

Table 5. Means, St.D and proportional means of E.G after using flipped classroom Model

\begin{tabular}{llcccc}
\hline No & \multicolumn{1}{c}{ Statement } & M & S.D & Prop M. & R \\
\hline 1. & FC encourages me to work individually & 4.44 & 0.50 & 88.80 & 5 \\
2. & Recorded materials help me to speak fluently & 4.56 & 0.54 & 91.20 & 1 \\
3. & FC gives me enough time to train in speaking & 4.48 & 0.54 & 89.60 & 4 \\
4. & The given recorded materials promote my speaking skills & 4.56 & 0.54 & 91.20 & 1 \\
5. & FC makes learning speaking more effective & 4.50 & 0.54 & 90.00 & 3 \\
6. & This style reduces my pronunciation mistakes & 3.78 & 0.91 & 75.60 & 9 \\
7. & Videos, handouts motivate me to practice speaking & 4.10 & 0.84 & 82.00 & 6 \\
8. & Listening to audios helps me to learn correct English & 3.92 & 0.80 & 78.40 & 7 \\
9 & Mini Pictionary encourages me to select vocabulary & 3.80 & 0.81 & 76.00 & 8 \\
10 & Assigned topics for the next lesson are prepared perfectly & 3.76 & 0.74 & 75.20 & 10 \\
11 & Recorded guidelines promoted speaking quality & 3.52 & 1.15 & 70.40 & 14 \\
12 & FC created a healthy learning environment & 3.38 & 1.01 & 67.60 & 19 \\
13 & This style helps me to be an independent learner & 3.52 & 1.22 & 70.40 & 14 \\
14 & Some teachers are reluctant to using technology & 3.72 & 1.13 & 74.40 & 11 \\
15 & The teacher has enough time to guide us towards debating & 3.50 & 1.13 & 70.00 & 17 \\
16 & My teacher became my companion in learning & 3.46 & 1.13 & 69.20 & 18 \\
17 & FC created an interactive atmosphere in speaking class & 3.52 & 1.01 & 70.40 & 14 \\
18 & Recorded voice encourages me to use good English & 3.60 & 1.11 & 72.00 & 13 \\
19 & FC doesn't contribute to improving learning speaking & 3.66 & 1.30 & 73.20 & 12 \\
20 & Lack of technology and instability of the internet doesn't help & 3.28 & 1.16 & 65.60 & 20 \\
& & 3.85 & 0.20 & 77.06 & \\
\hline
\end{tabular}

Table 5 reveals that the proportional mean of the total score of E.G is high = (77.06). This result means that FC Model has a high impact on the experimental group members.

Statements $(2,4)$ (Recorded materials help me to write correct sentences) (The given handouts promote organizing my ideas) had the highest proportional means but statements (12, 20) (Flipping created interesting lessons) (Lack of technology in my home city doesn't help) had the lowest proportional means.

The findings of the application showed that most students in the E.G made outstanding progress in their language oral skills although there were some did not check the materials at home. Flipped classroom gave all learners ample time to review and prepare materials beforehand individually. The class time was invested in the application part of the lessons including evaluation, creation and analyzing the given information face-to-face in the classroom. Additionally, the result of pre and posttests demonstrated noticeable progression in the participants' performance since it had enough exposure to the teaching materials. Both students and teachers had a positive attitude toward the flipped methodology.

The qualitative method was also employed to enrich the collected data and come out with accurate data. The interview was conducted with the participants in the current study to support the result of using a flipped classroom model. So, all of the interviewee's responses were gathered and analyzed thematically. Here are some extracts of participants' reactions towards flipping learning strategy.

\section{Students' reactions}

\section{Extract 1}

"FC would be an interesting strategy to fix the gap in my competence. We experienced positive interaction with teachers and partners when conducting debates, discussions, describing posters, tell stories, compare and contrast speech."

\section{Extract 2}

"We had more access to course materials. Listening to my teacher's guides at home was beneficial. I could speak fluently after practicing speaking skills. Watching guideline videos and listening to the recorded materials encouraged us to enhance input". 
Integrating the qualitative method in this study provides positive responses toward flipping class as a style of enhancing learning quality. As it was illustrated, the participants in this study announced that flipping motivated the engaged students in learning. The majority of students had positive interaction with the teacher and peers. Also, they indicated that they had a positive attitude towards using FC since they prepare themselves before going to the class (Extract 1). They also enjoyed that technique since they watch the teacher's recorded video-clips (Extract 2).

\section{Teachers' reactions}

Extract 1

"...flipping classroom is an important strategy to reverse classroom activities with assignments. The problem with that system is that some students are uncommitted to achieve what they have to study before coming to the classroom".

\section{Extract 2}

"Flipping class is recent to secondary school students in Oman but if this strategy is run perfectly, it will come out with successful results. The videos recorded materials and other instructional supportive materials online must be well thought out, designed and prepared perfectly beforehand. Flipped classroom saves classroom time and teachers can train students on carrying out speaking in real situations".

\section{Extract 3}

"...video-clips and audio recorded materials give students enough chance to use what is to be done in the class act their pace. This strategy may be a panacea to overcome difficulties students encounter since they lack exposure to good English. On the one hand, some teachers feel unhappy with incorporating technology along with a traditional classroom. Such blended learning will be accepted since it is new to students but some teachers are ill-trained".

The above teachers' responses indicate that FC is an important strategy since it reverses class activities with home-work but they state that some students lag in preparing what is assigned for the following day (Extract 1). They also declare that $\mathrm{FC}$ is a novice but it works if is used employed properly. They argue that teachers should be well-trained to prepare teaching materials online. Teachers have to exploit the FC strategy to invest classroom time thoroughly (Extract 2). They add that some teachers are reluctant to use technology beside classroom activities but some tome they accept it as a new system. Teachers' competence in technology integration; good competence in technology, the accessibility of technology lack of training in using technology appropriately (Extract 3).

Flipping learning is applicable in linguistic classrooms but there are some obstacles to use such a strategy since it needs persistence from teachers and students as well. Although students require much practice, the traditional approach is enjoyable to most students since they consider it easy to just receive information from the teacher's side. Moreover, producing teaching contents requires well-trained teachers who have the ability to prepare well-organized and teachable videos. Difficulty in-class activities and watching videos frustrate students since the recorded materials are prepared unsuccessfully. Besides, internet breakdown affects students' online activities such as watching video-clips and following guidelines towards achieving speaking tasks. The flipped classroom is an ineffectual teaching strategy in some classrooms due to weakness and lack of confidence in achieving online tasks. Further, monitoring students at home needs rapport between teachers and students and training towards independent learning. Additionally, preparing recorded materials is not easy since it requires skillful and well-trained teachers.

\section{CONCLUSION}

This paper intends to explore the possibility of using the FC model in a Secondary School in Oman to check its impact on the students' speaking performance and the participants' attitudes towards having such a strategy to enhance speaking skills. The result shows that FC motivates students to work hard and listen to the recorded materials furnished online. FC technique increases class activities, share knowledge autonomously but it is unwelcomed by inexperienced. Further, this study reveals that the new system affects students' attitudes positively. The blended strategy is highly appreciated by both teachers and students since it is applicable in EFL/ ESL classrooms but there are some 
impediments may discourage some educators to include FC in classrooms.

Flipping classroom strategy is an important strategy to grant students enough opportunity to absorb the prescribed teaching content. Since technological devices are in everyone's hand, teachers can start flipping in a small group to check the applicability of using this strategy among learners then extend flipping to all students in the class. It is recommended to teachers to give students a small number of assignments to avoid boring tasks. Training programs should be planned for teachers to acquire the skills necessary for using this model. Also, it is important to ensure that students watch video-clips before coming to class. Students can be trained gradually to reduce their dependence on teachers. However, the majority of students eager to have their teacher explanation in classrooms even though they resist using technology in learning the English language. Anyhow, further works towards autonomous learning are required to incorporate technology in education.

\section{ACKNOWLEDGEMENT}

I am thankful for and fortunate enough to get constant encouragement and support from my family who helped me to complete this work successfully. Also, I would like to extend my sincere esteem to all who always give me help in doing research.

\section{REFERENCES}

Aaron, S., \& Bergmann, J. (2012). Flip your classroom: Reach every student in every class every day. Washington, D.C: ISTE.

Abeysekera, L. \& Dawson, P. (2015). Motivation \& cognitive load in the flipped classroom: Definition, rationale, and a call for research. Higher Education Research \& Development, 34(1), 1-14. Retrieved from http:dx.doi.org/10.1080/0729436014.934336.

Akarawang, C., Kidrakran, P., \& Nuangchanlerm, P. (2015). Enhancing ICT competency for teachers in the Thailand basic education system. International Education Studies, 8(6), 1 -8.

Alsamdani, H. A. (2010). The relationship between Saudi EFL students' writing competence, L1 writing proficiency, and self-regulation. European Journal of Social Science, 16(1), 53-63.
Anderson, L. W., \& Krathwohl, D. (2001). A taxonomy for learning, teaching, and assessing: A revision of bloom's taxonomy of educational objectives. New York: Longman.

Atteberry, E. (2013). Flipped classrooms may not have any impact on learning. USA Today. Retrieved April 3, 2019 from http://www.usatoday.com/story/news/national/201 3/10/22.flippedclassrooms-effectiveness/31447.

Avdic, A., \& Akerblom, L. (2015). Flipped classroom and learning strategies. Proceedings of $14^{\text {th }}$ European conference on e-Learning. London: Academic Conferences Publishing.

Bakar, N. A., Latiff, H., \& Hamat, A. (2013). Enhancing ESL learners speaking skills through an asynchronous online discussion forum. Asian Social Science, 9(9), 224-233. doi: 10. 5539/ass.v9n9 p224.

Benson, P. (2011). Teaching and researching autonomy ( $2^{\text {nd }}$ ed.). Harlow, UK: Pearson Longman.

Bergman, J., \& Sams, A. (2012). Flip your classroom: Reach every student in every class every day. New York: Iste ASCD.

Bergman, J., \& Sams, A. (2013). Flip your students' learning. Educational Leadership, 70(6), 16-20.

Berrett, D. (2012). How flipping the classroom can improve the traditional lecture. The Chronicle of Higher Education. Retrieved on May 21, 2019 from

https://people.ok.ubc.ca/cstother/How_Flipping_th e_Classroom_Can_Improve_the_Traditional_Lect ure.pdf.

Bishop, J. L., \& Verleger, M. A. (2013). The flipped classroom: A survey of the research. ASEE National Conference Proceedings, Atlanta.

Brame, C. (2013). Flipping the classroom. Retrieved on May 21, 2019 from http://cft.vanderbilt.edu/guides-sub-pages/flippingthe-classroom/.

Clark, K. (2015). The effects of the flipped model of instruction on student engagement \& performance in the secondary mathematics classroom. Journal of Educators Online, 12(1), 91-115.

Curtis, B. J. C., \& Graham, C. R. (2006). The handbook of blended learning, global perspectives, local design. San Francisco: Pfeiffer.

Demski, J. (2013). Sic expert tips for flipping the classroom. Campus Technology, 25(5), 32-37.

Fleming, N. D. (2001). Teaching and learning styles: VARK strategies. Honolulu Community College.

Fraga, L. M., \& Harmon, J. (2014). The flipped classroom model of learning in higher education: An investigation of preservice teachers' perspectives and achievement. Journal of Digital Learning in Teacher Education, 31(1), 18-27.

Herreid, C. F., \& Schiller, N. A. (2013). Case studies and the flipped classroom. Journal of College Science Teaching, 42(5), 62-66. 
Ibrahim, H. A., \& Yusoff, S. Z. (2012). Teaching Public Speaking in a Blended Learning Environment. International Journal of Social Science and Humanity, 2(6), 573-576.

Kirkooz, Y. (2011). A blended learning study on implementing video recorded speaking tasks in task-based classroom instruction. The Turkish Online Journal of Educational Technology, 10(4), $1-13$.

Kurk, G., \& Atay, D. (2007). Students's writing apprehension. Journal of Theory and Practice in Education, 3(1), 12 -23.

Lage, M. G., \& Treglia, M. (2000). Inverting the classroom: A gateway to creating an inclusive learning environment. Journal of Economic Education, 31(1), 30-43.

Lemmer, C. (2013). A view from the flip side: Using the inverted classroom to enhance the legal information literacy of the international LLM student. Law Library Journal, 105(4), 46-491.

Lin, L. (2002). The effects of features films upon learners' motivation, listening \& speaking skills: The learner-centered approach. Retrieved from ERIC database (ED 470811).

Nguyen, B. T. (2013). Face-to-face, blended, and online instruction: Comparison of student performance and retention in higher education. Unpublished doctoral dissertation. Retrieved on February 22, 2015 from Proquest Digital Dissertation (AAT 3499473).

Osgerby, I. (2013). Students' perceptions of the introduction of a blended learning environment: An exploratory case study. Accounting Education,
22(1), 85-99. Retrieved from https://doi.org/10.1080/09639284.2012.729341.

Oxford, R. L. (2003). Language learning styles and strategies: An overview. Learning Styles \& Strategies. Oxford: GALA.

Pedroni, M., \& Meyer, B. (2006). The inverted curriculum in practice. Unpublished Proceedings of SIGCSE 2006, ACM, Houston, Texas.

Prince, M. (2004). Does active learning work? A review of the research. Journal of Engineering Education, 93(3), 223-231.

Rababah, G. (2003). Communication problems facing Arab learners of English: A personal perspective. TEFL Web Journal, 2(1), 15-30.

Rivero, V. (2013). A new model to reach all students in all ways. Internet @ school, 20(1), 14-16.

Sams, A., \& Bergmann, J. (2013). Flip your students' learning. Educational Leadership, 70(6), 16-20.

Street, S. E., Gilliland, K. O., McNeil, C., \& Royal, K. (2015). The flipped classroom improved medical student performance and satisfaction in a preclinical physiology course. Medical Science Educator, 25(1), 35-43.

Wiginton, B. L. (2013). Flipped instruction: An investigation into the effect of the learning environment on student self-efficacy, learning style, and academic achievement in an Algebra I classroom. Unpublished Dissertation. University of Alabama.

Wu, W. V. V, Chen Hsieh, J. S., \& Yang, J. C. (2017). Creating an Online Learning Community in a Flipped Classroom to Enhance EFL Learners' Oral Proficiency. Educational Technology \& Society, 20(2), 142-157. 
Yahya Ashour AlKhoudary

The effectiveness of flipping classroom model on EFL secondary school speaking skills 